\title{
Calvatia nodulata, a New Gasteroid Fungus from Brazilian Semiarid Region
}

\author{
Dônis da Silva Alfredo, ${ }^{1}$ Ana Clarissa Moura Rodrigues, ${ }^{1}$ and Iuri Goulart Baseia ${ }^{2}$ \\ ${ }^{1}$ Programa de Pós-Graduação em Sistemática e Evolução, Centro de Biociências, Universidade Federal do Rio Grande do Norte, \\ Campus Universitário, 59072-970 Natal, RN, Brazil \\ ${ }^{2}$ Departamento Botânica e Zoologia, Centro de Biociências, Universidade Federal do Rio Grande do Norte, Campus Universitário, \\ CEP 59072-970 Natal, RN, Brazil
}

Correspondence should be addressed to Dônis da Silva Alfredo; donis.alfredo@yahoo.com.br

Received 6 May 2014; Accepted 30 June 2014; Published 21 July 2014

Academic Editor: Terezinha Inez Estivalet Svidzinski

Copyright (C) 2014 Dônis da Silva Alfredo et al. This is an open access article distributed under the Creative Commons Attribution License, which permits unrestricted use, distribution, and reproduction in any medium, provided the original work is properly cited.

\begin{abstract}
Studies carried out in tropical rain forest enclaves in semiarid region of Brazil revealed a new species of Calvatia. The basidiomata were collected during the rainy season of 2009 and 2012 in two states of Northeast Brazil. Macroscopic and microscopic analyses were based on dried basidiomata with the aid of light microscope and scanning electron microscope. Calvatia nodulata is recognized by its pyriform to turbinate basidiomata, exoperidium granulose to pilose and not persistent, subgleba becoming hollow at maturity, nodulose capillitium, and punctate basidiospores $(3-5 \mu \mathrm{m})$. Detailed description, taxonomic comments, and illustrations with photographs and drawings are provided.
\end{abstract}

\section{Introduction}

The genus Calvatia was established by Fries in 1849 and is characterized by globose to pyriform basidiomata, with a subgleba and a dehiscence occurring by irregular fragmentation of the peridium in the upper portion of the basidioma, leaving the gleba exposed (Morgan [1], Coker and Couch [2], and Cunningham [3]). Calvatia species are distributed worldwide but mostly occur in arid, semiarid, and tropical regions (Lange [4]). In this context, the "brejos" are included, the term utilized to refer to tropical rain forest enclaves located in the semiarid Northeast Brazil (Santos et al. [5]).

Several studies have attempted to organize the genus (Lange [4], Zeller and Smith [6], Morales and Kimbrough [7], and Martín [8]), and some authors classify Calvatia as a species complex (Kreisel [9-11]). The studies of the molecular phylogeny (Larsson and Jeppson [12], Bates et al. [13]) have not been decisive in the elucidation of the relationship of the monophyly of Calvatia. However, Bates et al. [13] showed one clade of Calvatia s. str. with good support to North American specimens, but these results should not be taken as definitive. In the present paper, we therefore considered the classification based on morphology date in accordance with Calonge and Martín [14].

In Brazil, several mycologists have contributed to the knowledge of this group (Hennings [15], Silveira [16], Rick [17], Baseia [18], Wartchow and Silva [19], Baseia and Calonge [20], Cortez et al. [21], Cortez and Alves [22], and Alves and Cortez [23]). However, there were no records for the genus Calvatia in "brejos." These areas harbor many endemic species (Joppa et al. [24]), but their biota have not been properly analyzed. Therefore, the aim of this work is to expand the knowledge about the genus Calvatia, describing a new taxon from "brejos" of Northeast Brazil.

\section{Materials and Methods}

Fieldwork was carried out during the rainy season of 2009 and 2012 in three localities: (1) Área de Proteção Ambiental da Serra de Ibiapaba/CE $\left(03^{\circ} 39^{\prime} 80.6^{\prime \prime} \mathrm{S} 40^{\circ} 57^{\prime} 62.5^{\prime \prime} \mathrm{W}\right)$, (2) Parque Botânico do Ceará/CE $\left(03^{\circ} 42^{\prime} 50.35^{\prime \prime} \mathrm{S} 38^{\circ} 38^{\prime} 28.12^{\prime \prime} \mathrm{W}\right)$, and (3) Reserva Ecológica Estadual Mata do Pau-Ferro/PB $\left(06^{\circ} 57^{\prime} 89.9^{\prime \prime} \mathrm{S} 35^{\circ} 44^{\prime} 95.6^{\prime \prime} \mathrm{W}\right)$. All of them are located in 


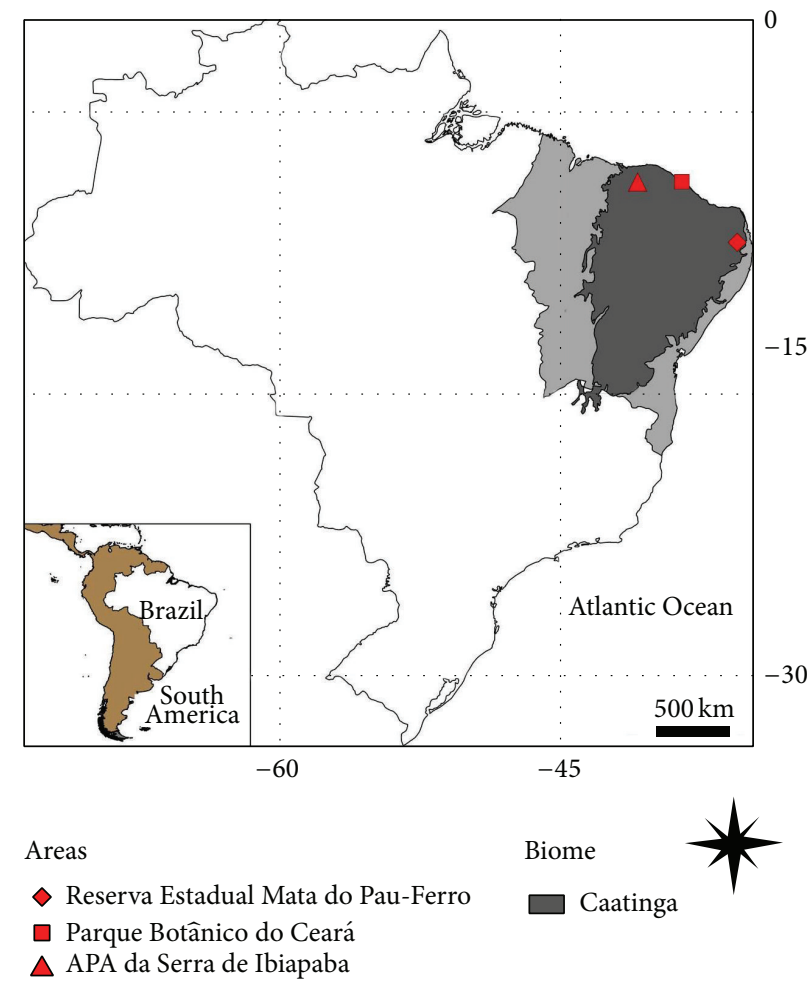

FIGURE 1: Map showing localities of fieldwork in tropical rain forest enclaves in Northeast Brazil.

tropical rain forest enclaves in Northeast Brazil (Figure 1). Moreover, in order to conduct comparative studies, dried specimens were borrowed from the Herbarium of the Universidade Federal do Rio Grande do Norte (UFRN). Macroscopic and microscopic analyses were based on dried basidiomata. For microscopic observations, sections were mounted in $5 \% \mathrm{KOH}$ and Melzer's reagent on glass slides (Baseia and Calonge [20], Alfredo et al. [25]). These were examined and photographed under a light microscope (LM) Nikon Eclipse Ni with NIS-Elements support software. Thirty randomly selected basidiospores were measured (including ornamentation) under LM at 1000x magnification (Alfredo and Baseia [26]). The basidiospores surfaces were examined under a Shimadzu SSX-550 scanning electron microscope (SEM) in accordance with Cortez et al. [27]. Statistic measures of basidiospores followed Silva et al. [28]. Line drawings were prepared and arranged using the camera lucida drawing tool. Color references followed Küppers [29]. Air-dried vouchers are deposited in the UFRN Herbarium.

2.1. Taxonomy. Calvatia nodulata Alfredo \& Baseia sp. nov. (Figures 2-5)

\section{Mycobank no.: MB804770.}

Diagnosis. Basidiomata 24-55 mm wide, pyriform to turbinate. Exoperidium granulose to pilose, not persistent. Subgleba occupying half of the basidiomata, disappearing at maturity leaving a hollow cavity. Basidiospores $3-5 \mu \mathrm{m}$ in diam., punctate. Capillitium 2-4 $\mu \mathrm{m}$ in diam., with spaced nodules.

Type: Brazil, Paraiba: Areia, Reserva Ecológica Estadual Mata do Pau-Ferro on decaying leaves, 17.06.2012, D. S. Alfredo n 97 (Holotype, UFRN-Fungos 1842).

Etymology: In reference to the capillitium, which present a nodulose surface.

Basidiomata 24-55 mm wide $\times 29-56 \mathrm{~mm}$ high, pyriform to turbinate. Exoperidium granulose to pilose, not persistent, brown $\left(\mathrm{N}_{90} \mathrm{Y}_{90} \mathrm{M}_{70}\right)$ in base becoming olive brown $\left(\mathrm{N}_{70} \mathrm{Y}_{80} \mathrm{M}_{40}\right)$ in apex, with sand incrusted. Endoperidium papery, surface smooth to wrinkly, plicate, light brown $\left(\mathrm{N}_{50} \mathrm{Y}_{99} \mathrm{M}_{20}\right)$ to brown $\left(\mathrm{N}_{50} \mathrm{Y}_{99} \mathrm{M}_{50}\right)$. Gleba initially cottony becoming powdery olive brown $\left(\mathrm{N}_{60} \mathrm{Y}_{80} \mathrm{M}_{20}\right)$ at maturity. Subgleba occupying half of the basidioma, initially cottony and in someone disappearing at maturity, leaving a hollow cavity, tapered at the base attached to the substrate. Rhizomorphs scarce, $<0.5 \mathrm{~mm}$ thick, whitish.

Basidiospores 3.1-4.7 $\mu \mathrm{m} \times 2.9-4.6 \mu \mathrm{m}(x=4.1 \pm 0.3 \times$ $3.9 \pm 0.4 ; \mathrm{Qm}=1.05 ; n=30)$, subovoid to ampulliformis, punctate, pedicels $0.5-3.7 \mu \mathrm{m}$ length, hyaline to pale in $5 \%$ $\mathrm{KOH}$, light brown in Melzer's reagent (weak reaction). Capillitium lycoperdon-type, 2-4 $\mu \mathrm{m}$ diam., hyphae with straight walls $<1.5 \mu \mathrm{m}$ thick, often ornamented with spaced nodules (0.5-1.5 $\mu \mathrm{m}$ high), occasionally branched and septate, rare circular pits, pale yellow in $5 \% \mathrm{KOH}$, without reaction in Melzer's reagent. Paracapillitium absent. Exoperidium composed of subglobose, claviform, pyriform, obpyriform to 


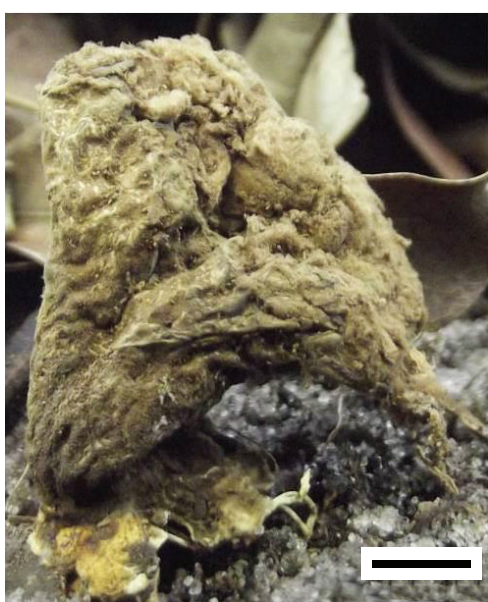

(a)

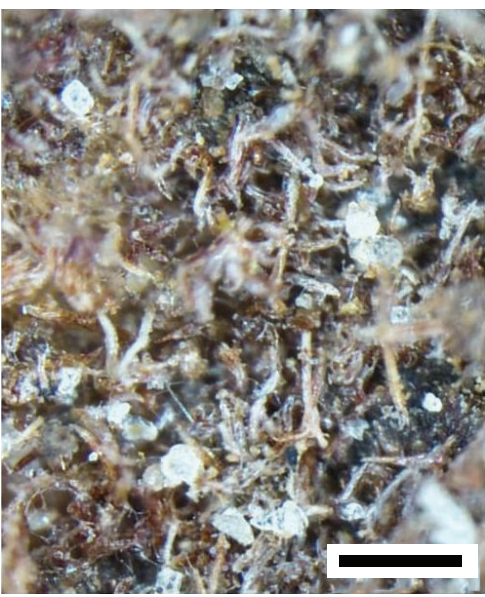

(c)

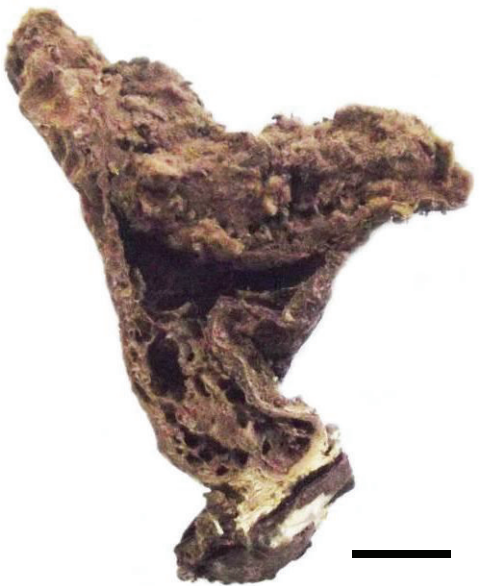

(b)

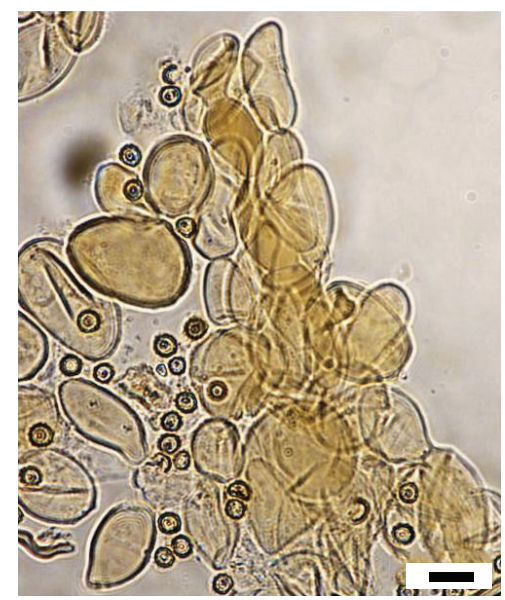

(d)

FIGURE 2: Calvatia nodulata: (a) basidioma on leaf decaying, bar $=5 \mathrm{~mm}$; (b) basidioma cross-sectional showing the hollow cavity of subgleba, bar $=5 \mathrm{~mm}$; (c) detail of pilose exoperidium, bar $=0.2 \mathrm{~mm}$; (d) detail chains of cells of exoperidium under light microscopic, bar $=10 \mu \mathrm{m}$.

elliptic hyphae, 7.5-26.5 $\mu \mathrm{m} \times 12.7-40.5 \mu \mathrm{m}$, walls $<1,5 \mu \mathrm{m}$ thick, pale yellow in $5 \% \mathrm{KOH}$. Endoperidium $3-5.7 \mu \mathrm{m}$ diam., hyphae straight, walls $<1.5 \mu \mathrm{m}$ thick, brittle, interwoven, light brown in 5\% KOH. Subgleba hyphae $1.5-4.5 \mu \mathrm{m}$ diam., branched, sinuous walls, pale yellow in $5 \% \mathrm{KOH}$. Rhizomorphs with two types of hyphae: one thinner outer $1.5-4.5 \mu \mathrm{m}$ diam., aseptate, hyaline in $5 \% \mathrm{KOH}$, dextrinoid in Melzer's reagent; one thicker inner 10-27.5 $\mu \mathrm{m}$ diam., septate, hyaline in $5 \% \mathrm{KOH}$ and light brown in Melzer's reagent (weak reaction).

Distribution and habitat-known to date from Brazil, growing solitary or two basidiomata on decaying leaves.

Specimens examined-Calvatia nodulata (Paratypes): Brazil, Ceará: Viçosa do Ceará, 03.03.2005, R. S. Araújo n ${ }^{\circ} 108$ (UFRN-Fungos 995); Tianguá, Serra de Ibiapaba, 19.04.2012, D. S. Alfredo n 76 (UFRN-Fungos 1843); Caucaia, Parque Botânico do Ceará, 29.03.2009, R. S. Chikowski \& T. L. D. Silva $n^{\circ} 18$ (UFRN-Fungos 2119); Paraiba: Areia, Reserva Ecológica Estadual Mata do Pau-Ferro, 15.07.2013, J. O. Sousa \& D. S. Alfredo n 167 (UFRN-Fungos 2120).
Additional material examined-Calvatia rugosa: Brazil Rio Grande do Norte: Serra Negra do Norte, Estação Ecológica do Seridó, 18.02.2007, M. M. B. Barbosa s.n. (UFRN-Fungos 924); Calvatia sp.: ibid., 18.02.2007, B. D. B. Silva, E. P. Fazolino \& J. J. S. Oliveira s.n. (UFRN-Fungos 399); Vascellum pratense: Natal, Parque Estadual Dunas do Natal, 08.08.2004, I. G. Baseia \& M. M. B. Barbosa s.n. (UFRN-Fungos 300); Calvatia cyathiformis: João Câmara, Cauaçu, 04.2012, T. S. Accioly s.n. (UFRN-Fungos 1769, UFRN-Fungos 1770).

Notes. Calvatia nodulata is mainly characterized by its exoperidium not persistent, subgleba occupying half of the basidiomata and in some disappearing at maturity, leaving a hollow cavity, punctate basidiospores, and capillitium hyphae with spaced nodules (Figures 2-5). Initially, Calvatia nodulata can be confused with a representative of the genus Vascellum Smarda due to the diaphragm-like subgleba hollow (Figure 2(b)) separating the base of the gleba. However, Vascellum species show a well-developed apical pore or 


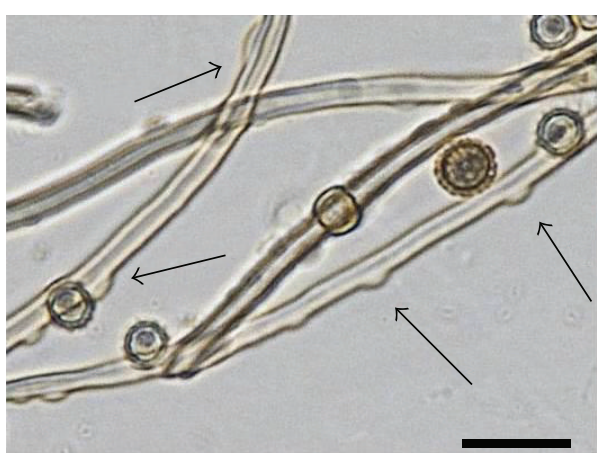

(a)

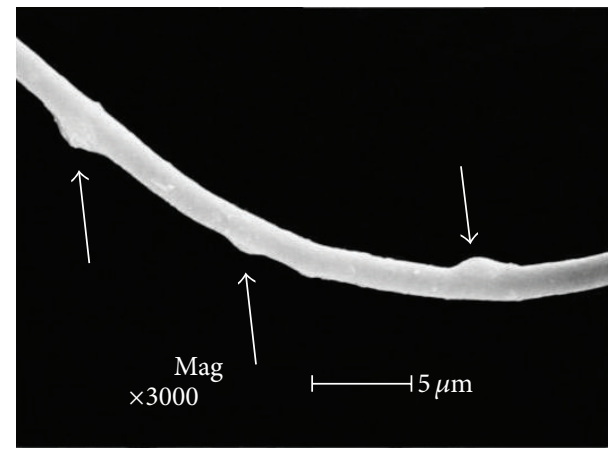

(c)

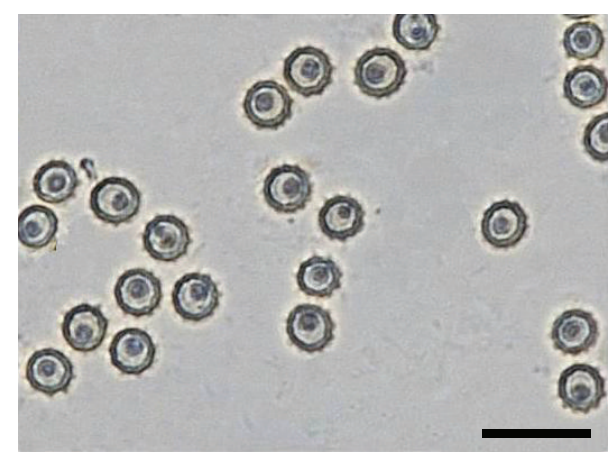

(b)

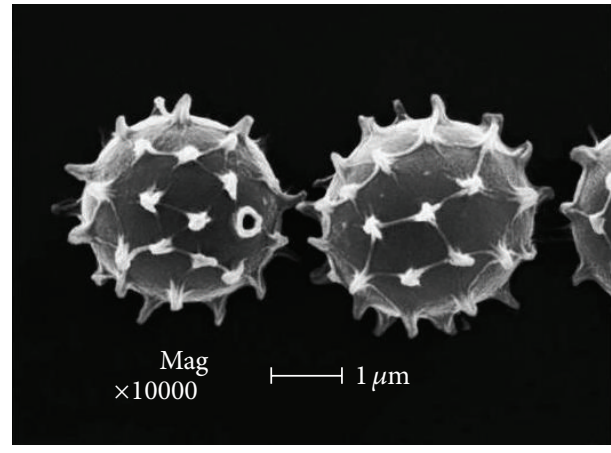

(d)

Figure 3: Microstructures of Calvatia nodulata: (a) nodulate capillitium indicated by arrows, bar $=10 \mu \mathrm{m}$; (b) punctate basidiospores, bar $=10 \mu \mathrm{m}$; (c) nodulate capillitium indicated by arrows under SEM, bar $=5 \mu \mathrm{m}$; (d) punctate basidiospores with ornamentation connected by grooves under SEM, bar $=1 \mu \mathrm{m}$.

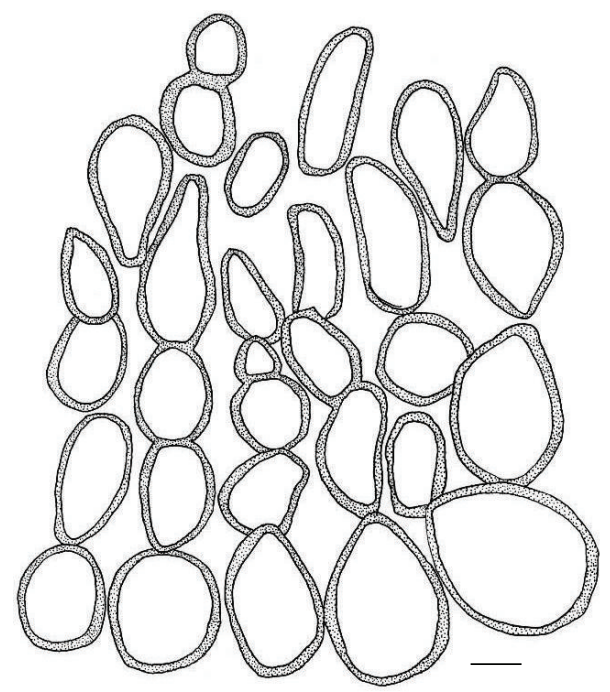

(a)

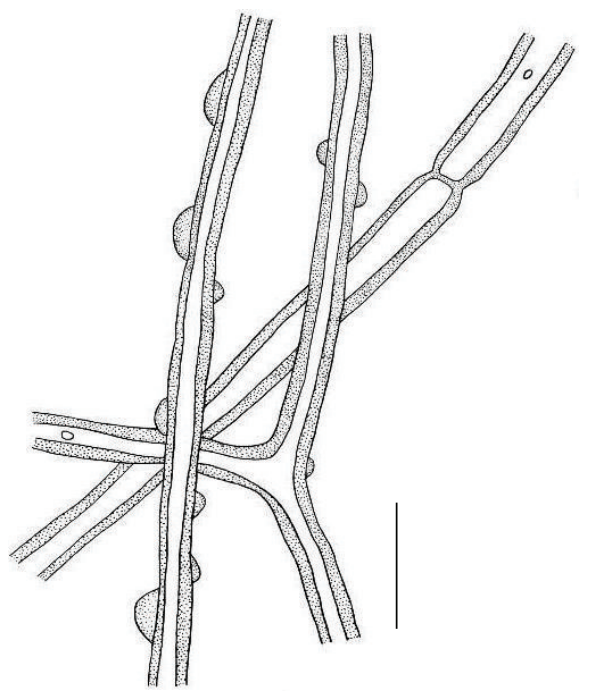

(b)

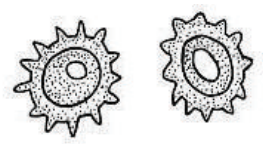

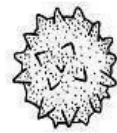

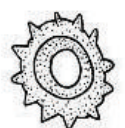

(c)

FIGURE 4: Drawings of microstructures of Calvatia nodulata: (a) chains of cells of exoperidium, bar $=10 \mu \mathrm{m}$; (b) ornamentation of capillitium, bar $=10 \mu \mathrm{m}$; (c) punctate basidiospores, bar $=5 \mu \mathrm{m}$.

dehiscence irregular star-shaped (Ponce de Leon [30] and Homrich [31]). In Calvatia nodulata, dehiscence occurs by disintegration of peridium, fully exposing the gleba (Figures 2(a)-2(b)).
The dehiscence and other features, such as septate capillitium, branched and ornamented (Figures 3(a), 3(c), and 4(b)) and punctate basidiospores (Figures 3(b), 3(d), and 4(c)), make these materials closely related to Calvatia species. 


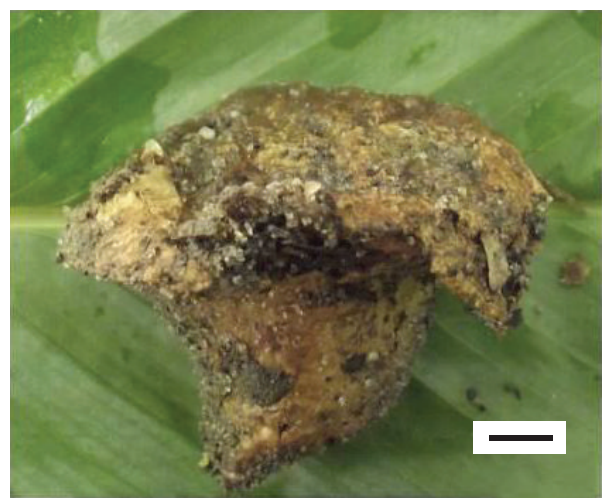

(a)

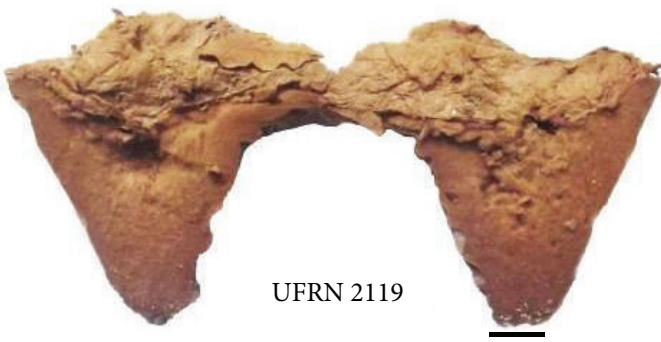

(c)

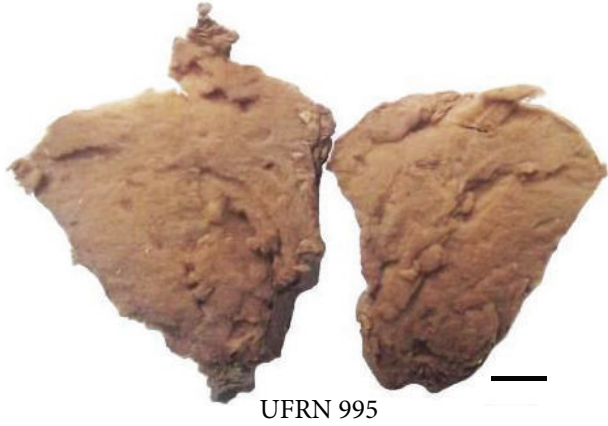

(e)

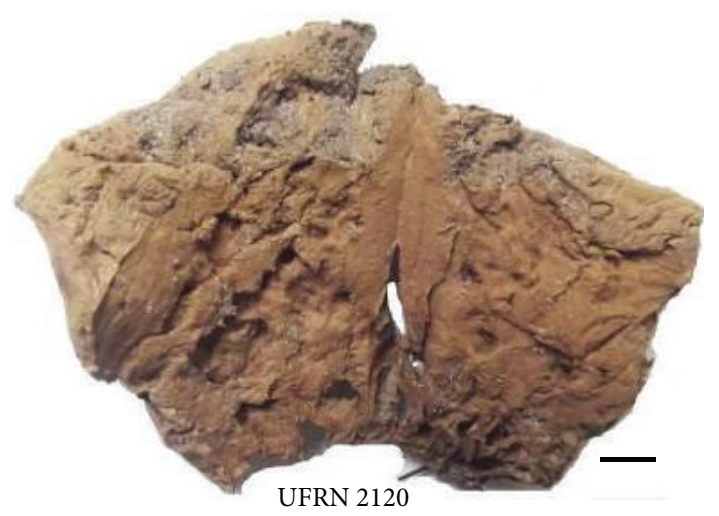

(b)

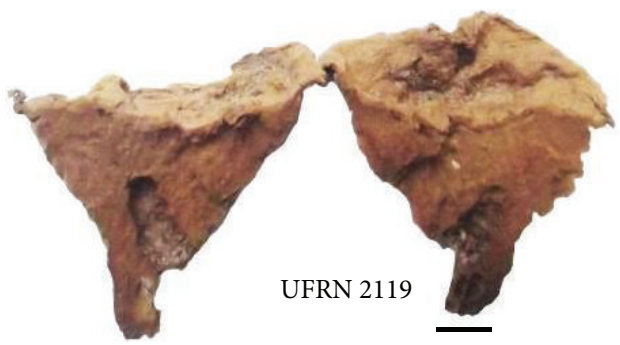

(d)

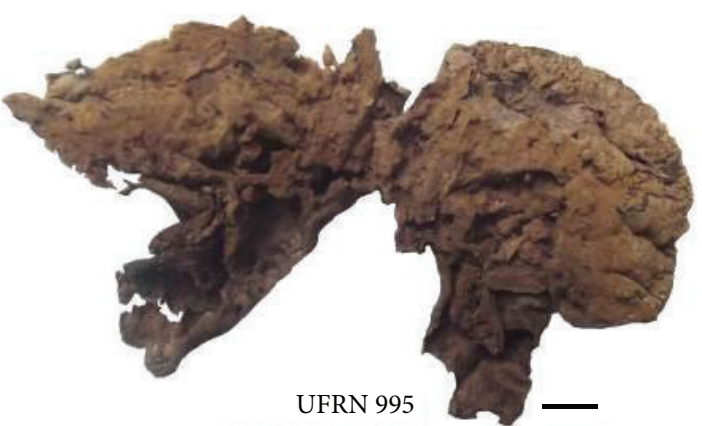

(f)

Figure 5: Different paratypes of Calvatia nodulata: (a) fresh basidioma collected in Reserva Ecológica Estadual Mata do Pau-Ferro; ((b)-(f)) dried basidiomata in cut sections: (b) basidioma collected in Paraiba state, Reserva Ecológica Estadual Mata do Pau-Ferro; (c) basidiomata collected in Ceará state, Parque Botânico do Ceará; (d) basidiomata collected in Ceará state, Viçosa do Ceará. All bars $=10 \mathrm{~mm}$.

During specimen studies the aforementioned characteristics show a close relationship with Calvatia rosacea Kreisel [9], but a thorough analysis separates these two species: Calvatia nodulata has a developed subgleba, which in some specimens disappears with age, leaving a hollow cavity (Figures 2(b) and 5), exoperidium granulose to pilose (Figure 2(c)), composed of subglobose to elliptical cells (Figures 2(d) and 4(a)) and nodulose capillitium hyphae (Figures 3(a), 3(c) and 4(b)). These characteristics are absent in C. rosacea, which exhibits an exoperidium furfuraceum and pink, endoperidium hyphae dextrinoid in Melzer's reagent, subgleba chambered, septate and smooth surface capillitium hyphae. Even Kreisel (page 293, Figure 6), although not calling attention to these characteristics, provides illustrations of exoperidium cells, making it clear that the cell arrangements in both species are distinct. Basidiospores of Calvatia nodulata and C. rosacea under LM are finely verrucose (Figure 3(b)), have small warts connected by grooves (Figure 3(d)) at the base, and are similar in these taxa.

Other species, such as C. pallida A. H. Sm. and C. depressa (Bon.) Zeller \& A. H. Sm., have only two similar characteristics to those of $C$. nodulata, such as size and basidiospores ornamentation (Zeller and Smith [6]). Calvatia rugosa (Berk. $\&$ M. A. Curtis) D. A. Reid, reported from Brazil, shows a basidiospore ornamentation similar to our species (Cortez et al. [21]). Calvatia nodulata is easily distinguished from Calvatia guzmanii C. R. Alves \& Cortez because C. guzmanii is characterized by a distinctly spinose exoperidium, smooth endoperidium, persistent subgleba, and smooth capillitium with abundant pores (Alves and Cortez [23]). These characteristics differ from those observed in C. nodulata, especially when compared with microstructures of the exoperidium and capillitium surface. 
Rodrigues et al. [32] reported Calvatia cyathiformis $\mathrm{f}$. cyathiformis (Bosc) Morgan also from Brazilian semiarid region, a less closely related species with $C$. nodulata. Its developed subgleba is similar, but the powdery gleba, septate, smooth and abundant pitted capillitial threads, and echinulate basidiospores are purplish brown at maturity, these sets of morphological features data are discrepant in C. nodulata. Other species, such as Calvatia sporocristata Calonge and Calvatia oblongispora V. L. Suárez, J. E. Wright \& Calonge, show elongated basidiospores quite similar to $C$. nodulata, but the dextrinoid endoperidium hyphae, brittle and smooth surface capillitium hyphae, and ellipsoid to amygdaloid basidiospores with crests-like ornamentation of C. sporocristata (Calonge et al. [33]) differ from the $C$. nodulata, whereas $C$. oblongispora is separate by its double exoperidium, various size pores capillitium with smooth surface, and cylindrico-ellipsoid basidiospores with aligned crests ornamentation (Suárez et al. [34]).

Calvatia ochrogleba Zeller shows subgleba with bluish tints of the tissues, gleba not falling out easily with cavities, globose, and large basidiospores (5-6.2 $\mu \mathrm{m})$ (Zeller [35]); these features distinguish $C$. nodulata mainly because it has different color subgleba and smaller size basidiospores (3$5 \mu \mathrm{m})$.

Given the arguments, these distinct characteristics found in Calvatia nodulata make a good support for establishing a new species.

\section{Conflict of Interests}

The authors declare that there is no conflict of interests regarding the publication of this paper.

\section{Acknowledgments}

The first and second authors would like to thank $\mathrm{CNPq}$ (Conselho Nacional de Desenvolvimento Científico e Tecnológico, Brazil) for providing the Master's scholarship. The authors are grateful for the financial support of the Programa de Pesquisa em Biodiversidade (PPBio Semi-arid). The authors also acknowledge the UFRN Herbarium for loaning the specimens and Renata dos Santos Chikowski for collecting some of the material used in this work and the field notes. The authors are grateful to Dr. Tine Grebenc (Slovenian Forestry Institute) for a critical review of the paper. The paper was corrected by an anonymous English native speaker.

\section{References}

[1] A. P. Morgan, "North American Fungi. Third paper: the gasteromycetes. Order II.: lycoperdaceae," Journal of the Cincinnati Society Natural History, vol. 12, pp. 163-173, 1890.

[2] W. C. Coker and J. N. Couch, The Gasteromycetes of the Eastern United States and Canada, University of North Carolina Press, Chapel Hill, NC, USA, 1928.

[3] G. H. Cunningham, The Gasteromycetes of Australia and New Zealand, John McIndoe, Dunedin, New Zealand, 1944.

[4] M. Lange, "Classifications in the Calvatia group," Blyttya, vol. 51, pp. 141-144, 1993.
[5] A. M. M. Santos, D. R. Cavalcanti, J. M. C. da Silva, and M. Tabarelli, "Biogeographical relationships among tropical forests in north-eastern Brazil," Journal of Biogeography, vol. 34, no. 3, pp. 437-446, 2007.

[6] S. M. Zeller and A. H. Smith, "The genus Calvatia in North America," Lloydia, vol. 27, no. 3, pp. 148-186, 1964.

[7] M. I. Morales and J. W. Kimbrough, "The lycoperdaceae of North Central Florida I. The genera Calvatia and Disciseda," Revista de Biología Tropical, vol. 11, pp. 227-236, 1978.

[8] M. P. Martín, "Exoperidium and spores of Calvatia utriformis," Mycotaxon, vol. 61, pp. 381-387, 1997.

[9] H. Kreisel, "Studies in the Calvatia complex (Basidiomycetes)," Nova Hedwigia, vol. 48, pp. 281-296, 1989.

[10] H. Kreisel, "An emendation and preliminary survey of the genus Calvatia (Gasteromycetidae)," Persoonia, vol. 14, pp. 431-439, 1992.

[11] H. Kreisel, "Die Gattungen Calvatia und Handkea in Europa und der Arktis," Österreichische Zeitschrift für Pilzkunde, vol. 7, pp. 215-225, 1998.

[12] E. Larsson and M. Jeppson, "Phylogenetic relationships among species and genera of Lycoperdaceae based on ITS and LSU sequence data from North European taxa," Mycological Research, vol. 112, no. 1, pp. 4-22, 2008.

[13] S. T. Bates, R. W. Roberson, and D. E. Desjardin, "Arizona gasteroid fungi I: Lycoperdaceae (Agaricales, Basidiomycota)," Fungal Diversity, vol. 37, pp. 153-207, 2009.

[14] F. D. Calonge and M. P. Martín, "Notes on the taxonomical delimitation in the genera Calvatia, Gastropila and Langermania (Gasteromycetes)," Boletín Sociedad Micológica de Madrid, vol. 14, pp. 181-190, 1990.

[15] P. Hennings, "Fungi S. Paulenses III a cl. Puttemans collecti," Hedwigia, vol. 43, pp. 208-209, 1904.

[16] V. D. Silveira, "O gênero Calvatia para o Brasil," Rodriguésia, vol. 16, pp. 63-80, 1943.

[17] J. Rick, "Basidiomycetes Eubasidii no Rio Grande do Sul," Iheringia, vol. 9, pp. 451-480, 1961.

[18] I. G. Baseia, "Contribution to the study of the genus Calvatia (Lycoperdaceae) in Brazil," Mycotaxon, vol. 88, pp. 107-112, 2003.

[19] F. Wartchow and S. M. Silva, "Primeira ocorrência de Calvatia cyathiformis (Basidiomycota) em Caatinga, Estado de Pernambuco, Brasil," Sitientibus Série Ciências Biológicas, vol. 7, pp. 176177, 2007.

[20] I. G. Baseia and F. D. Calonge, "Calvatia sculpta, a striking puffball occurring on Brazilian sand dunes," Mycotaxon, vol. 106, pp. 269-272, 2008.

[21] V. G. Cortez, I. G. Baseia, and R. M. B. da Silveira, "Gasteroid mycobiota of Rio Grande do Sul, Brazil: Calvatia, Gastropila and Langermannia (Lycoperdaceae)," Kew Bulletin, vol. 67, no. 3, pp. 471-482, 2012.

[22] V. G. Cortez and C. R. Alves, "Type study of Calvatia lachnoderma from Brazil”, Mycosphere, vol. 3, pp. 894-898, 2012.

[23] C. R. Alves and V. G. Cortez, "Calvatia guzmanii sp. nov. (Agaricaceae, Basidiomycota) from Paraná State, Brazil," Phytotaxa, vol. 85, no. 2, pp. 35-40, 2013.

[24] L. N. Joppa, P. Visconti, C. N. Jenkins, and S. L. Pimm, "Achieving the conservation on biological diversity's goals for plant conservation," Science, vol. 6, pp. 1100-1103, 2013.

[25] D. S. Alfredo, T. Accioly, and I. G. Baseia, "Morganella arenicola, a new species record from North and Northeast Brazil," Turkish Journal of Botany, vol. 38, pp. 595-599, 2014. 
[26] D. S. Alfredo and I. G. Baseia, "Morganella nuda, a new puffball (Agaricaceae, Basidiomycota) in the upland forests of the Brazilian semi-arid region," Nova Hedwigia, vol. 98, pp. 459466, 2014.

[27] V. G. Cortez, I. G. Baseia, R. T. Guerrero, and R. M. B. Silveira, "Two sequestrate cortinarioid fungi from Rio Grande do Sul, Brazil," Hoehnea, vol. 35, pp. 513-518, 2008.

[28] B. D. B. Silva, J. O. Sousa, and I. G. Baseia, "Discovery of Geastrum xerophilum from the Neotropics," Mycotaxon, vol. 118, pp. 355-359, 2011.

[29] H. Küppers, Atlas de los colores, Blume, Barcelona, Spain, 2002.

[30] P. Ponce de Leon, "Revision of the genus Vascellum," Fieldiana: Botany, vol. 32, pp. 109-125, 1970.

[31] M. H. Homrich, O gênero Vascellum smarda na América do meridional [M.S. thesis], Universidade Federal do Rio Grande do Sul, Porto Alegre, Brazil, 1975.

[32] A. C. M. Rodrigues, D. S. Alfredo, and I. G. Baseia, "Lycoperdaceae," in Fungos Gasteroides no Semiárido do Nordeste Brasileiro, I. G. Baseia, B. D. B. Silva, and R. H. S. F. Cruz, Eds., pp. 57-70, Print Mídia, Rio Grande do Norte, Brazil, 2014.

[33] F. D. Calonge, M. Mata, and J. Carranza, "Calvatia sporocristata sp. nov. (Gasteromycetes) from Costa Rica," Revista de Biologia Tropical, vol. 51, no. 1, pp. 79-84, 2003.

[34] V. L. Suárez, J. E. Wright, and F. D. Calonge, "Calvatia oblongispora sp. nov. from Brazil, with close affinities to C. sporocristata from Costa Rica," Mycotaxon, vol. 108, pp. 323-327, 2009.

[35] S. M. Zeller, "More notes on Gasteromycetes," Mycologia, vol. 39, no. 3, pp. 282-312, 1947. 

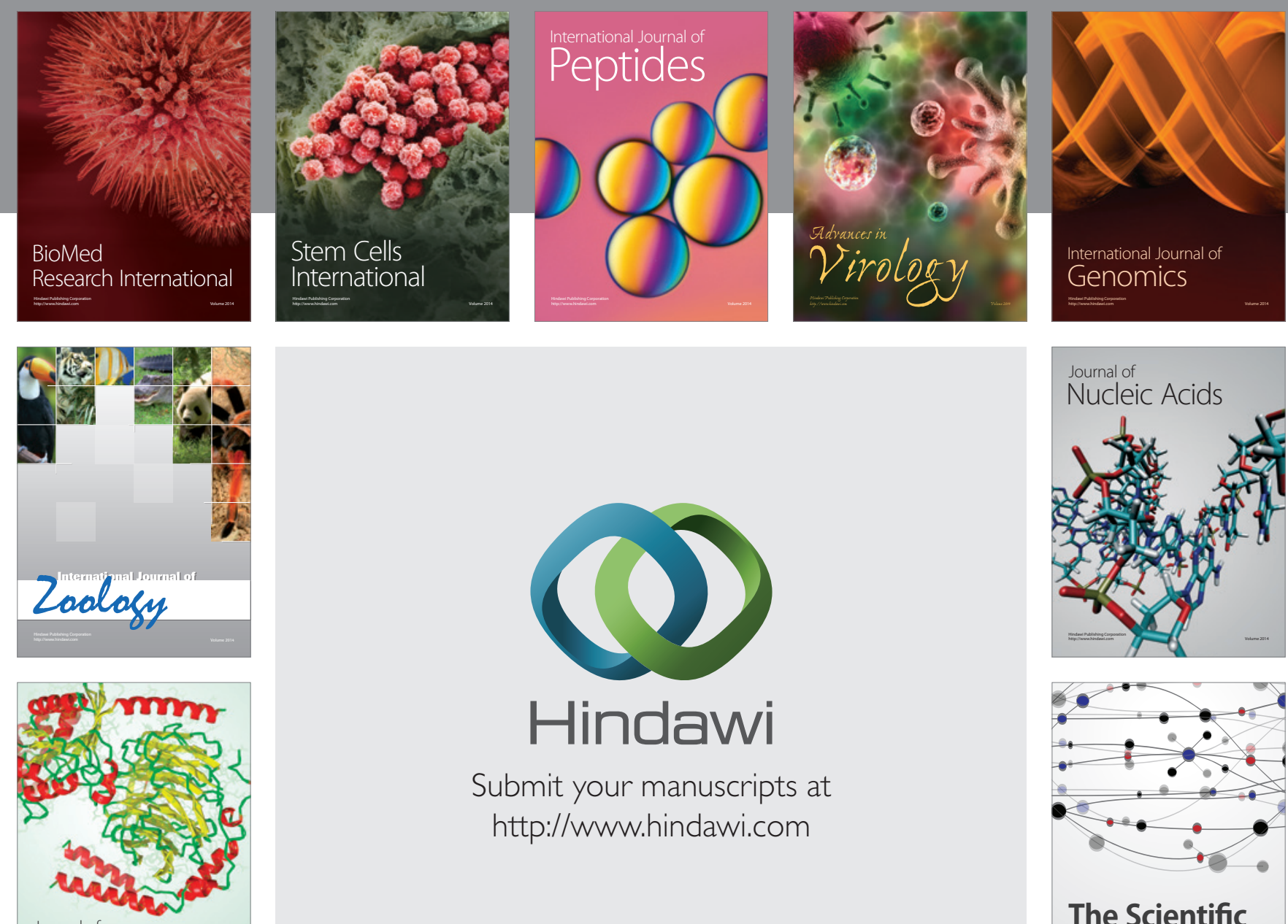

Submit your manuscripts at

http://www.hindawi.com

Journal of
Signal Transduction
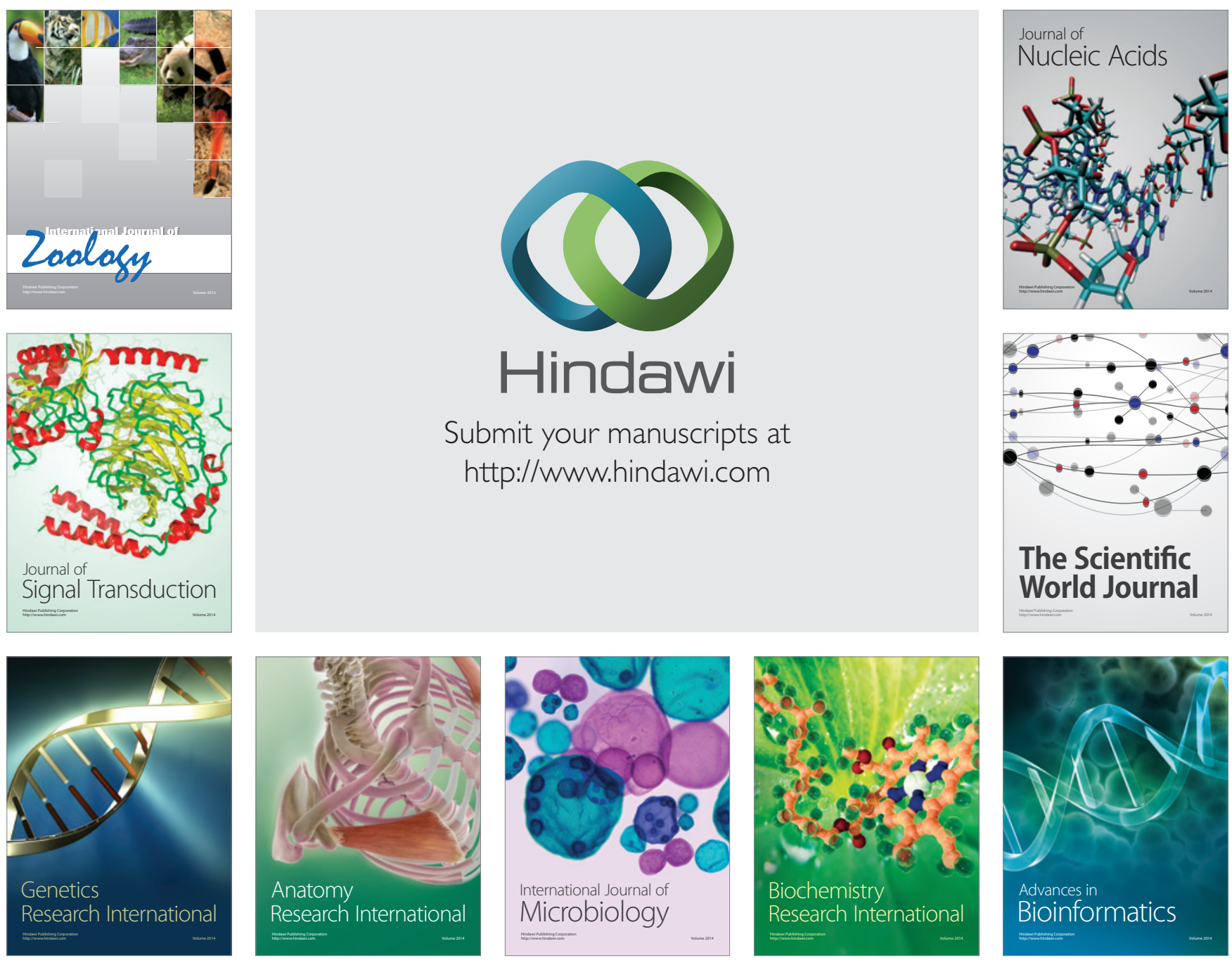

The Scientific World Journal
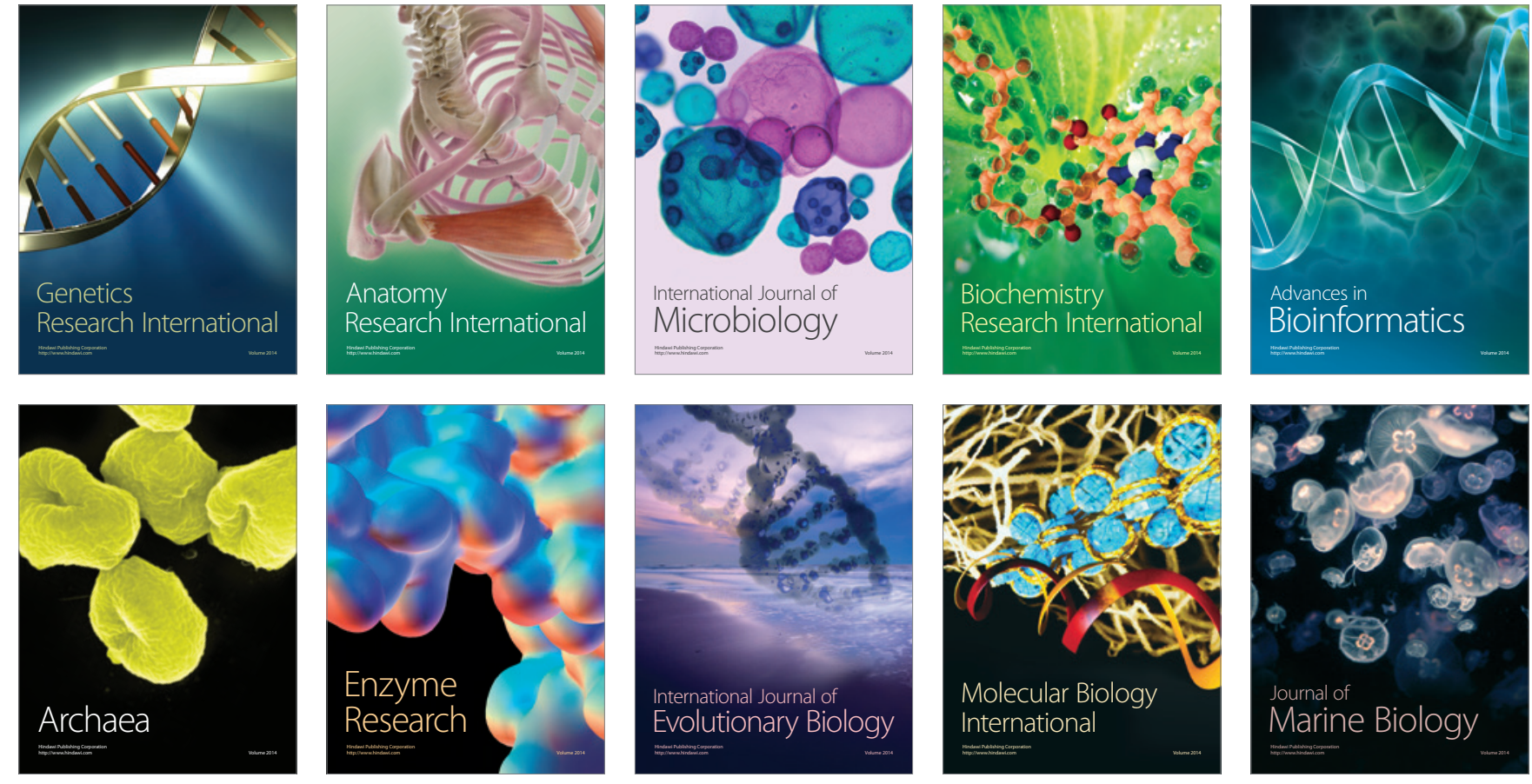